\title{
Prague: A New Golem
}

\author{
By Jan Uhde
}

Spring 1995 Issue of KINEMA

THE ANCIENT LEGEND about Rabbi Löw and the human-sized clay figure Golem whom the Rabbi brought to life only to see his creation become a destructive force is closely tied to Prague, one of Europe's cultural marvels. The famous Paul Wegener's proto-expressionist 1915 film, Golem, was also shot in that city. This year, a new Golem is about to be born: An international film festival Golden Golem 95 will be held in Prague for the first time between 9-17 June. Its categories include International Competition for feature-length films, Panorama of World film, Czech film, Independent film, a Retrospective, a Film market, and others.

\section{Author Information}

Jan UHDE is Professor Emer. (Film Studies) at the University of Waterloo, Ontario, Canada. Born in Brno, Czech Republic. Graduated (MA) from the Faculty of Arts, Masaryk University, Brno; PhD received at the University of Waterloo, Ontario, Canada. He taught at the University of Waterloo (1970-2012) where he founded a General and Honours BA program in Film Studies at the Department of Fine Arts.

Publications: Latent Images: Film in Singapore Second edition, with Yvonne Ng Uhde (Ridge Books, National University Press of Singapore, 2010); Latent Images: Film in Singapore, with Yvonne Ng Uhde (Oxford University Press, 2000); Latent Images: Film in Singapore CD-ROM (2003, co-author); Vision and Persistence: Twenty Years of the Ontario Film Institute (University of Waterloo Press, 1990) and Ontario Film Institute Programming Activities Index 1969-1989 (Toronto: Ontario Science Centre, 1990). He co-edited the Place in Space: Human Culture in Landscape (Proceedings from the Second International Conference of the Working Group "Culture and Landscape" of the International Association of Landscape Ecology, Pudoc Scientific Publishers, Wageningen, Holland, 1993). Jan Uhde has published articles and reviews in several countries (including Canada, USA, Germany, Italy), participated in international juries at film festivals and presented papers at international conferences in North America and Europe. In 1998/99, he was a visiting researcher at the School for Film and Media Studies, Ngee Ann Polytechnic, Singapore.

His professional and research interests focus on Singapore cinema; the identification and distancing mechanisms of the film viewer; the non-authored modifications and manipulation of films; and specific aspects of film history, including the Central European cinema.

He founded KINEMA in 1993. 